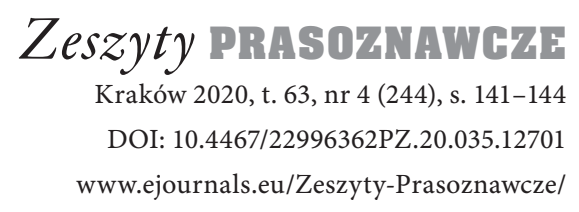

\title{
ISTOTNE PYTANIA
}

Kazimierz Wolny-Zmorzyński: Biblia a korzenie reportażu. Glosa do historii i teorii gatunku. Wydawnictwo Adam Marszałek, Toruń 2020, s. 189.

Podjęcie tematyki biblijnej jest świadectwem dojrzałości i powagi Autora. Równocześnie oznacza ryzyko wystawienia się na pytania dotyczące wielu rozległych i trudnych problemów.

W tej recenzji pozostawimy na boku spory o okoliczności i daty powstawania ksiąg biblijnych, porównywanie ich wersji, kształtowanie kanonu czy też trafność tłumaczeń. Tego dociekają specjaliści. Kierujemy uwagę na konkretne dzieło, a mianowicie Nowy Testament w wersji opracowanej przez Edycję Świętego Pawła (2009). Przedmiotem badania podjętego przez Autora były wszystkie księgi Nowego Testamentu poza Apokalipsą św. Jana. Określał je w skrócie jako Ewangelie i tego terminu będziemy się trzymać.

Autor spojrzał na Ewangelie okiem medioznawcy, specjalisty w zakresie gatunków dziennikarskich, a zwłaszcza reportażu. Swoją pozycję określił wyraźnie, deklarując się jako zwolennik podziału tekstów na dwie rozłączne kategorie. Do pierwszej zaliczył teksty literackie, dopuszczające fikcję. Do drugiej - teksty dziennikarskie, w tym reportażowe, dokumentujące rzeczywiste wydarzenia. Takie stanowisko doprowadziło do wniosków, które nie brzmią jednoznacznie. Autor najwyraźniej wykazał się brakiem konsekwencji.

W części swoich stwierdzeń Autor bywa ostrożny. Deklaruje zamiar odnalezienia w Ewangeliach korzeni gatunkowych reportażu (s. 7) i odnajduje w Ewangeliach elementy reportażu (s. 10). Ewangelie przypominają Autorowi reportaż retrospektywny (s. 108). Badacz stwierdza też, iż Ewangelie można uznać za prototyp reportażu (s. 158). Z takimi wnioskami zgodzi się każdy uważny czytelnik. Reportaż nie pojawił się przecież jako gotowy współczesny gatunek dziennikarski, lecz jest wynikiem długiej ewolucji. U jego początków leżą liczne warianty klasycznych dzieł, recytowane wedle zapamiętanych formuł i typowych schematów, lecz zarazem improwizowane przez narratorów przed publicznością w trakcie różnych, często rytualnych uroczystości. Każdy wykonawca był w takich przypadkach jednym z wielokrotnych autorów, a każde wykonanie - nową wersją utworu (Mich 2020). 
Pozostałe stwierdzenia Autora brzmią zdecydowanie, a jego spojrzenie staje się współczesne. Ewangelie mówią o zdarzeniach historycznych i prawdziwych (s. 17), Ewangelie są dokumentem zawierającym prawdziwe szczegóły z życia Jezusa (s. 40), autorzy Ewangelii byli wiernymi rejestratorami rzeczywistości (s. 71), Ewangelie mają wszystkie cechy reportażu, autorzy Ewangelii mówią prawdę, podają rzetelnie zbadane i sprawdzone fakty (s. 163).

W tym miejscu skołowany czytelnik zadaje sobie pytanie: jak było naprawdę? Czy Ewangelie rzetelnie przedstawiają rzeczywiste wydarzenia? Współcześnie dociec tego się nie da, choć można w to uwierzyć. Pojawiają się zatem dwa inne wielkie pytania: czym różni się wiedza od wiary oraz jak poznajemy rzeczywistość?

Odpowiedź na pierwsze z powyższych pytań zaproponował Leszek Kołakowski (2000, 2003), odróżniając wiedzę technologiczną od wiedzy mitycznej. Wiedza technologiczna wynika z empirycznego poznania i jest potwierdzona przez praktykę, pozwala na przewidywanie zdarzeń i kontrolowanie ich przebiegu. Zarazem jest to wiedza tymczasowa, gdyż stale pozostaje otwarta na nowe doświadczenia i odkrycia. Wiedza mityczna jest natomiast niezależna od okoliczności poznania, dotyczy genezy świata i sensu wydarzeń. Pytania mityczne nie dają się przełożyć na pytania technologiczne, lecz mimo to są dla człowieka niezbędne. Technologiczny i mityczny punkt widzenia są obecne w każdym człowieku, ich współżycie jest nieuchronne i niemożliwe zarazem, a wynikający z nich konflikt wartości ożywia naszą kulturę - konkluduje Kołakowski.

Powyższe skrótowe przedstawienie finezyjnego rozumowania znajduje swoiste potwierdzenie w aforystycznym początku encykliki „Fides et Ratio” Jana Pawła II (1998): „Wiara i rozum są jak dwa skrzydła, na których duch ludzki unosi się ku kontemplacji prawdy".

Próba odpowiedzi na drugie pytanie zawiera się między pojęciami lektury i konstrukcji. Czy świat jest gotową i spójną księgą, jaką należy uważnie czytać? Takie podejście wyraził na przykład Michał Heller (1984, s. 60, 89), z aprobatą cytując przy tym Alberta Einsteina: „Najbardziej niezrozumiałą rzeczą we wszechświecie jest to, że wszechświat jest zrozumiały". Zastrzegał zarazem, iż w siatce praw fizyki są wolne miejsca otwarte na działanie przypadku (Heller 2012, s. 310). Odmienne podejście wskazuje na znaczenie konstrukcji. Spostrzec jakiś przedmiot to znaczy uczynić ten przedmiot treścią świadomości poznającego podmiotu. Przedmiot poznania zostaje ukonstytuowany przez poznający podmiot (Ajdukiewicz 2003, s. 57-58). Może zatem poznanie zaczyna się od percepcji rozumianej jako lektura, po czym niektóre spostrzeżenia są pomijane, a inne włączane do istniejącej wcześniej w umyśle, mniej lub bardziej prowizorycznej konstrukcji? Alfred Schütz (2012, s. 10, 18, 143) określił ową prowizoryczną konstrukcję jako świat życia codziennego. Jest to zestaw nieproblematycznych, czyli przyjmowanych jako oczywiste, założeń dotyczących wiedzy o świecie, częściowo podzielanych z innymi ludźmi, choć niekoniecznie kompletnych, uporządkowanych ani spójnych. Świat życia ma różne stopnie jasności i wyrazistości. Jest wynikiem edukacji i socjalizacji jednostki. Stanowi zadowalającą podstawę interpretowania doświadczanego wycinka rzeczywistości, 
dokonywanego jako nakładanie matrycy świata życia na ów nieokreślony początkowo wycinek rzeczywistości.

Mówiąc skrótowo, kiedy dwie osoby patrzą na to samo, niekoniecznie widzą to samo. Zręcznie wyraził to Stanisław Jerzy Lec: „Koniom i zakochanym inaczej pachnie siano" (Lec 1974, s. 12).

Czy nie jest zatem tak, iż wykazana na początku tej recenzji niekonsekwencja Autora jest wynikiem poruszania się w polu napięć wytworzonym przez różne bieguny? Raz Autor zbliża się do bieguna wiedzy technologicznej, zachowując rezerwę wobec takich danych, jakie nie dają się potwierdzić zmysłami, a innym razem ulega przyciąganiu bieguna wiedzy mitycznej, ufnie przyjmując stwierdzenia zgodne z pewną wizją świata i człowieka, lecz wymykające się empirycznemu poznaniu. Raz jest bliski biegunowi lektury i traktuje badany tekst jak wierną kalkę rzeczywistości, innym razem przybliża się do bieguna konstrukcji i zastrzega, że treść Ewangelii jest wynikiem selekcji materiału oraz dostosowania go do potrzeb i możliwości poznawczych ówczesnych odbiorców.

Ewentualne przyjęcie takiego podejścia ma konsekwencje w postaci zakwestionowania dychotomicznego podziału na teksty literackie i teksty dziennikarskie. Wszystkie teksty będą umieszczone w polu napięcia pomiędzy jeszcze innymi dwoma biegunami. Jednym z nich jest biegun obiektywizmu, do którego można się zbliżać, lecz nigdy nie uda się go osiągnąć, gdyż w pełni obiektywne może być tylko boskie spojrzenie z zaświatów. Drugim będzie biegun fikcji, oznaczający swobodne bajdurzenie bez jakiegokolwiek związku z rzeczywistością. W takim przypadku pojęcia reportażu literackiego i literatury faktu nie są oksymoronem, jak chce Autor (s. 159-160), lecz oznaczają teksty umieszczone w polu napięcia obu powyższych biegunów, zbliżające się do jednego bądź drugiego, lecz nieosiągające żadnego z nich.

Powyższe stwierdzenia nie są zarzutem wobec Autora. Pozostaje jego zasługą, iż o wielu ważnych pytaniach przypomniał, lecz nie musiał ich przecież rozstrzygać. „Pośród wielu pytań podtrzymujących europejską filozofię przy życiu przez dwa i pół tysiąclecia ani jedno nie zostało nigdy rozstrzygnięte ku naszemu powszechnemu zadowoleniu" (Kołakowski 1990, s. 7).

\section{Bibliografia}

Ajdukiewicz K. (2003). Zagadnienia i kierunki filozofii. Teoria poznania i metafizyka. Kęty-Warszawa. Heller M. (1984). Usprawiedliwienie wszechświata. Kraków.

Heller M. (2012). Filozofia przypadku. Kosmiczna fuga z preludium i codą. Kraków.

Jan Paweł II (1998). Fides et Ratio [http://www.vatican.va/content/john-paul-ii/pl/encyclicals/ documents/hf_jp-ii_enc_14091998_fides-et-ratio.html; 22.04.2020].

Kołakowski L. (1990). Horror metaphysicus. Warszawa.

Kołakowski L. (2000). Kultura i fetysze. Warszawa.

Kołakowski L. (2003). Obecność mitu. Warszawa.

Lec S.J. (1974). Myśli nieuczesane. Kraków. 
Mich W. (2020). O kreatywności poetów oralnych. Zeszyty Prasoznawcze, nr 1 (241), s. 27-40.

Pismo Święte Starego i Nowego Testamentu. Najnowszy przekład z języków oryginalnych z komentarzem (2009). Częstochowa.

Schütz A. (2012). O wielości światów. Szkice z socjologii fenomenologicznej. Kraków.

Wojciech Furman

(iD) orcid.org/0000-0002-5643-3281 